\title{
Calcium in the production and quality of cauliflower seeds
}

\author{
Cálcio na produção e qualidade de sementes de couve-flor \\ Calcio en la producción y calidad de semillas de coliflor
}

Pâmela Gomes Nakada-Freitas ORCID: https://orcid.org/0000-0002-2429-0423 Universidade Estadual Paulista, Brasil E-mail: pamela.nakada@unesp.br

Juliana Tamires dos Santos

ORCID: https://orcid.org/0000-0002-7960-4020 Universidade Estadual Paulista, Brasil E-mail: ju_santos95@outlook.com

Gabriel Ferraresi Hidalgo

ORCID: https://orcid.org/0000-0003-1520-181X Universidade Estadual Paulista, Brasil E-mail: gabriel.f.h@hotmail.com

Louyne Varini Santos dos Anjos ORCID: http://orcid.org/0000-0002-6934-1909 Universidade Estadual Paulista, Brasil E-mail: louyne_gav@hotmail.com Emanuele Possas de Souza

ORCID: https://orcid.org/0000-0002-8039-2176 Universidade Estadual Paulista, Brasil E-mail: maanu.pss@gmail.com Isabela Ribeiro Martins

ORCID: https://orcid.org/0000-0002-8239-4212 Universidade Estadual Paulista, Brasil E-mail: hortifrutime@outlook.com

Antonio Ismael Inácio Cardoso

ORCID: https://orcid.org/0000-0003-3251-9491 Universidade Estadual Paulista, Brasil

E-mail: antonio-ismael.cardoso@unesp.br

Estefânia Martins Bardiviesso

ORCID: https://orcid.org/0000-0001-7331-9491 Universidade Estadual Paulista, Brasil

E-mail: estefania.bardiviesso@ hotmail.com

Natália de Brito Lima Lanna

ORCID: https://orcid.org/0000-0001-6228-0392 Associação Biodinâmica, Brasil

E-mail: nataliabllanna@gmail.com

Hugo Cesar Rodrigues Moreira Catão ORCID: https://orcid.org/0000-0002-6232-6351

Universidade Federal de Uberlândia, Brasil E-mail: hugo.catao@ufu.br

Reges Heinrichs

ORCID: https://orcid.org/0000-0001-9461-9661 Universidade Estadual Paulista, Brasil E-mail: reges.heinrichs@unesp.br

\begin{abstract}
There are researches with calcium to produce the cauliflower inflorescence, but for seeds production no studies were found, this element is fundamental for the fixation of the floral buds and in the production and quality of seeds. The objective was to evaluate the effect of foliar application of calcium on different phenological stages of cauliflower plants in seed production and quality. Eleven treatments were evaluated, varying the number (1 to 4$)$ of calcium $\left(6 \mathrm{~g} \mathrm{~L}^{-1}\right.$ of calcium chloride) applications and the phenological stages $(\mathrm{E} 1=$ floral stem with $30 \mathrm{~cm}$ length, $\mathrm{E} 2=$ opening of the first flowers; $\mathrm{E} 3=$ formation of first siliques; $\mathrm{E} 4=50 \%$ of silique formed), resulting: $\mathrm{T} 1=$ control without application of $\mathrm{Ca} ; \mathrm{T} 2=\mathrm{E} 1 ; \mathrm{T} 3=\mathrm{E} 1+\mathrm{E} 2 ; \mathrm{T} 4=\mathrm{E} 1+\mathrm{E} 2+\mathrm{E} 3 ; \mathrm{T} 5=\mathrm{E} 1+\mathrm{E} 2+\mathrm{E} 3+\mathrm{E} 4 ; \mathrm{T} 6=\mathrm{E} 2 ; \mathrm{T} 7=\mathrm{E} 2+\mathrm{E} 3 ; \mathrm{T} 8=\mathrm{E} 2+\mathrm{E} 3+$ $\mathrm{E} 4 ; \mathrm{T} 9=\mathrm{E} 3 ; \mathrm{T} 10=\mathrm{E} 3+\mathrm{E} 4 ; \mathrm{T} 11=\mathrm{E} 4$. The results showed a higher seed production per plant in treatments $\mathrm{T} 10(\mathrm{E} 3+$ E4) and T11 (E4) with 42 and 48 g per plant, and a higher number of seeds per plant, with 12,379 and 12,978, respectively, compared to the control (T1): $23 \mathrm{~g}$ and 5,725 seeds per plant. Calcium applications in different
\end{abstract}


phenological stages did not influence the physiological quality (germination and vigor) of cauliflower seeds of cultivar 'Piracicaba Precoce'. Application of these treatments in other cultivars is promising for further studies.

Keywords: Brassica oleracea var. botrytis; Calcium chloride; Germination; Vigor.

\begin{abstract}
Resumo
Existem pesquisas com uso de cálcio para produzir couve-flor de consumo comercial, mas para a produção de sementes não foram encontrados estudos. Este elemento é fundamental na fixação dos botões florais e portanto, na produção e qualidade das sementes. O objetivo foi avaliar o efeito da aplicação foliar de cálcio nos diferentes estágios fenológicos das plantas de couve-flor na produção e qualidade de sementes. Foram estudados 11 tratamentos, variando número (1 a 4) de aplicações de cálcio (6 g L-1 de cloreto de cálcio) e estádios fenológicos (E1 = haste floral com $30 \mathrm{~cm}$; E2 = abertura das primeiras flores; E3 = formação das primeiras síliquas; E4 = 50\% de síliquas formadas), resultando nos seguintes tratamentos: $\mathrm{T} 1=$ controle sem aplicação de Ca; T2 = E1; T3 = E1 + E2; T4 = E1 + E2 + E3; T5 = E1 + E2 + E3 + E4; T6 = E2; T7 = E2 + E3; T8 = E2 + E3 + E4; T9 = E3; T10 = E3 + E4; T11 = E4). O delineamento experimental foi em blocos casualizados, com quatro repetições. Foram obtidas maior massa de sementes por planta nos tratamentos T10 (E3 + E4) e T11 (E4), com 42 e 48 g de sementes por planta, assim como maior número de sementes por planta, com 12.379 e 12.978 sementes, respectivamente, comparativamente ao controle (T1): 23 g e 5.725 sementes por planta. As aplicações de cálcio em diferentes estádios fenológicos não influenciaram a qualidade fisiológica (germinação e vigor) de sementes de couve-flor 'Piracicaba Precoce'. Aplicação desses tratamentos em outras cultivares são promissores para novos estudos.
\end{abstract}

Palavras-chave: Brassica oleracea var. botrytis; Cloreto de cálcio; Germinação; Vigor.

\title{
Resumen
}

Hay investigaciones sobre el uso de calcio para producir coliflor para consumo comercial, pero no se han encontrado estudios para la producción de semillas. Este elemento es fundamental en la fijación de los botones florales y por tanto en la producción y calidad de las semillas. El objetivo fue evaluar el efecto de la aplicación foliar de calcio en las diferentes etapas fenológicas de plantas de coliflor sobre la producción y calidad de semillas. Se estudiaron once tratamientos variando el número ( 1 a 4$)$ de aplicaciones de calcio $\left(6 \mathrm{~g} \mathrm{~L}^{-1}\right.$ de cloruro de calcio) y estadios fenológicos $(\mathrm{E} 1$ = tallo floral de $30 \mathrm{~cm}$; E2 = apertura de las primeras flores; E3 = formación del primeras sílices; E4 = 50\% de sílices formadas), resultando en los siguientes tratamientos: $\mathrm{T} 1=$ control sin aplicación de Ca; $\mathrm{T} 2=\mathrm{E} 1 ; \mathrm{T} 3=\mathrm{E} 1+\mathrm{E} 2$; $\mathrm{T} 4=\mathrm{E} 1+\mathrm{E} 2+\mathrm{E} 3 ; \mathrm{T} 5=\mathrm{E} 1+\mathrm{E} 2+\mathrm{E} 3+\mathrm{E} 4 ; \mathrm{T} 6=\mathrm{E} 2 ; \mathrm{T} 7=\mathrm{E} 2+\mathrm{E} 3 ; \mathrm{T} 8=\mathrm{E} 2+\mathrm{E} 3+\mathrm{E} 4 ; \mathrm{T} 9=\mathrm{E} 3 ; \mathrm{T} 10=\mathrm{E} 3+\mathrm{E} 4 ;$ $\mathrm{T} 11$ = E4). El diseño experimental fue en bloques al azar, con cuatro repeticiones. Se obtuvo mayor masa de semillas por planta en los tratamientos T10 (E3 + E4) y T11 (E4), con 42 y 48 g de semillas por planta, así como mayor número de semillas por planta, con 12,379 y 12,978 semillas, respectivamente, comparativamente al control (T1): 23 g y 5.725 semillas por planta. Las aplicaciones de calcio en las diferentes etapas fenológicas no influyeron en la calidad fisiológica (germinación y vigor) de las semillas de coliflor 'Piracicaba Precoce'. La aplicación de estos tratamientos en otros cultivares es prometedora para futuros estudios.

Palabras clave: Brassica oleracea var. botrytis; Cloruro de cálcio; Germinación; Vigor.

\section{Introduction}

Although there are studies on nutrition and fertilization recommendations for cauliflower production, there are few studies about nutrient effects on seed production and quality. Due to the scarcity of information related to nutritional requirements, fertilization may compromise seed productivity and quality (Cardoso, 2011).

One nutrient that has been neglected in the research about the production of vegetable seeds is calcium. In cauliflower it is the third most accumulated nutrient in the plant (Cardoso et al., 2016). Its function is to act in the formation of the calcium pectate, present in the middle lamellar of the cell wall, in the germination of the pollen and pollen tube growth, being therefore a fundamental element for the fixation of the floral buds and in the production of seeds. Its deficiency in plants can result in poor biotic and abiotic stress tolerance, reduced crop quality and yield (Dayod et al., 2010).

Limestone is the main source of calcium and it is necessary to maintain an optimum soil moisture level to promote adequate movement of $\mathrm{Ca}$ to the roots and into the plant (Olle \& Bender, 2009).

Because the distribution of $\mathrm{Ca}$ in the plant is preferentially via xylem, the redistribution rate for fruits and seeds is very low (Olle \& Bender, 2009; Kano et al., 2010). Bevilaqua et al. (2002) suggested that the application of this nutrient should be done via foliar in the flowering or post-flowering phase in order to have a better use and, consequently, an increase in seed productivity, which has already been reported in soybean (Bevilaqua et al., 2002; Arantes et al., 2009), corn (Javorski et al., 
2015), Physalis (Silva et al., 2017), pomegranate (Hosein-Beigi et al., 2019) and beans (Rosolem et al., 1990). In cauliflower, there are researches with calcium to produce the inflorescence, but for seeds production no studies were found.

The objective of this research was to evaluate the effect of foliar application of calcium on different phenological stages of cauliflower plants in seed production and quality.

\section{Material and Methods}

The research was conducted at the São Paulo State University (Unesp), College of Agricultural and Techonogical Sciences, Dracena. It is located at $421 \mathrm{~m}$ altitude (coordinates $21^{\circ} 27^{\prime} 37^{\prime \prime}$ south latitude and $51^{\circ} 33^{\prime} 21^{\prime \prime}$ west longitude). The rainfall index is 1,236 mm per year and the climate of the region, according to the classification of Köppen, is Cwa type, with dry winter.

A total of 11 treatments were studied, varying number (1 to 4$)$ of calcium $\left(6 \mathrm{~g} \mathrm{~L}^{-1}\right.$ of calcium chloride, $27 \%$ of $\mathrm{Ca}$ ) and phenological stages $(\mathrm{E} 1=$ floral stem with $30 \mathrm{~cm}, \mathrm{E} 2=$ opening of the first flowers, $\mathrm{E} 3=$ formation of the first siliques, E4 $=50 \%$ of silique formed), resulting in the following treatments: $\mathrm{T} 1=$ control without application of $\mathrm{Ca} ; \mathrm{T} 2=\mathrm{E} 1 ; \mathrm{T} 3=\mathrm{E} 1+\mathrm{E} 2$; $\mathrm{T} 4=\mathrm{E} 1+\mathrm{E} 2+\mathrm{E} 3 ; \mathrm{T} 5=\mathrm{E} 1+\mathrm{E} 2+\mathrm{E} 3+\mathrm{E} 4 ; \mathrm{T} 6=\mathrm{E} 2 ; \mathrm{T} 7=\mathrm{E} 2+\mathrm{E} 3 ; \mathrm{T} 8=\mathrm{E} 2+\mathrm{E} 3+\mathrm{E} 4 ; \mathrm{T} 9=\mathrm{E} 3 ; \mathrm{T} 10=\mathrm{E} 3+\mathrm{E} 4 ; \mathrm{T} 11=\mathrm{E} 4$, these treatments being characterized as qualitative (Pereira et al., 2018). The experimental design was a randomized block, with four replications.

The soil chemical characteristics were: $\mathrm{pH}_{(\mathrm{CaCl} 2)}=4.6$; organic matter $=15 \mathrm{~g} \mathrm{dm}^{-3}, \mathrm{P}=4 \mathrm{mg} \mathrm{dm}^{-3} ; \mathrm{H}+\mathrm{Al}=22 \mathrm{mmol}_{\mathrm{c}}$ $\mathrm{dm}^{-3} ; \mathrm{K}=2.1 \mathrm{mmol}_{\mathrm{c}} \mathrm{dm}^{-3} ; \mathrm{Ca}=7 \mathrm{mmol}_{\mathrm{c}} \mathrm{dm}^{-3} ; \mathrm{Mg}=4 \mathrm{mmol}_{\mathrm{c}} \mathrm{dm}^{-3} ; \mathrm{SB}=13.1 \mathrm{mmol}_{\mathrm{c}} \mathrm{dm}^{-3} ; \mathrm{CEC}=35.1 \mathrm{mmol}_{\mathrm{c}} \mathrm{dm}^{-3}$ and $\mathrm{V}=$ $37 \%$. Correction of soil acidity, planting and cover fertilization were made according to the recommendations of Raij et al. (1997).

The cultivar Piracicaba Precoce was studied and the sowing was made on 03/04/2017 in trays of 162 cells, and transplantation was done 25 days after sowing (DAS) in the spacing of $1.0 \times 0.5 \mathrm{~m}$, the plot was composed of four plants. Leaf applications of sodium molybdate at a dose of $1.0 \mathrm{~g} \mathrm{~L}^{-1}$ were made at 30 and 45 days after transplanting (DAT).

The application of calcium chloride was started in plants with a floral stem of $30 \mathrm{~cm}$ at 69 DAT, and the others applications were made as the plants developed, according to the treatments (opening of the first flowers, formation of the first siliques, $50 \%$ of silique formed).

Seed harvesting started at 135 DAT when the silique was straw-yellow, not totally dry, and the seeds had a dark brown color (Contreras et al., 2014), and finished at 152 DAT.

After harvesting, the plants remained in a dry, shaded and ventilated place in order to lose moisture and facilitate the extraction of the seeds. After the extraction, the seeds were cleaned in the seed separator by density (De Leo Type 1 model), resulting in the classified seeds used in the evaluations. The seeds remained in a dry chamber $\left(40 \% \mathrm{RU}\right.$ and $\left.20^{\circ} \mathrm{C}\right)$ till the moisture content of the seeds stabilized at $8 \%$.

The evaluated characteristics were: plant height (evaluated on the day of harvest); dry weight of the plant: weight of the aerial part, without the seeds; weight of 1000 seeds (Brasil, 2009); number and weight of seeds per plant.

Germination and vigor of the seeds were also evaluated: a) germination test: according to the methodology of the Seed Analysis Rules (Brasil, 2009), and the number of normal seedlings evaluated at the $10^{\text {th }}$ day after sowing (DAS), expressed as a percentage; b) first germination count: the number of normal seedlings was counted at $5^{\text {th }}$ DAS on the germination test, expressed as a percentage; c) length of primary root and shoot: ten normal seedlings of the germination test at $10^{\text {th }}$ DAS were randomly sampled, measured and expressed in centimeters; d) seedling length: sum of the length measurement of the primary root and shoot, expressed in centimeters; e) seedling dry weight: normal germination test seedlings, collected at $10^{\text {th }}$ DAS, were placed in forced circulation air oven at $40^{\circ} \mathrm{C}$ and evaluated after weight stabilization, expressed in milligrams per seedlings; f) electrical 
conductivity: four replicates of 50 seeds, obtaining the weight in precision scale, then added $75 \mathrm{~mL}$ of deionized water, and remained in a chamber at $25^{\circ} \mathrm{C}$ for a period of 24 hours to perform the reading (Paiva et al., 2005), in a conductivity meter, expressed in $\mu \mathrm{S} \mathrm{cm}^{-1} \cdot \mathrm{g}^{-1}$.

The data were submitted to analysis of variance and the means were compared by the Scott-Knott test at 5\% probability.

\section{Results and Discussion}

Plant height (mean of $78 \mathrm{~cm}$ ) and plant dry weight (mean of $225 \mathrm{~g}$ ) were not affected by treatments, showing that Ca foliar application at plant stages studied does not affect these vegetative traits.

There was a higher weight and number of seeds per plant in the treatment T10 (two calcium applications in the last two stages: in the formation of the first siliques and when the plants were with $50 \%$ of the silique formed) and in the treatment T11 (one application in the last stage, plants with 50\% silique formed) (Table 1). With the increase in the cauliflower plant cycle for seed production, as well as a greater accumulation of dry weight in the seeds (Cardoso, 2011), there is a greater need for nutrients, among them calcium, which is not very mobile in the plant (Kano et al., 2010) and can be supplied via foliar application (Bevilaqua et al., 2002; Ole and Bender, 2009). According to Kano et al. (2011), the accumulation of Ca in the seeds occurs almost exclusively by absorption and transport during the formation and maturation of the seeds, without redistribution of the senescent leaves to the seeds.

Table 1. Height and dry weight of plant, weight and number of seeds per plant according to calcium applications in different phenological stages of the cauliflower plants.

\begin{tabular}{cccccc}
\hline Treatment & $\begin{array}{c}\text { Plant } \\
\text { height } \\
(\mathrm{cm})\end{array}$ & $\begin{array}{c}\text { Dry plant } \\
\text { weight } \\
(\mathrm{g})\end{array}$ & $\begin{array}{c}\text { Seed } \\
\text { weight per } \\
\text { plant }(\mathrm{g})\end{array}$ & $\begin{array}{c}\text { Number } \\
\text { of seeds } \\
\text { per plant }\end{array}$ & Yield \\
$\left(\mathrm{kg} \mathrm{ha}^{-1}\right)$
\end{tabular}

${ }^{1}$ Means followed by the same letter do not differ by the Scott-Knott test at $5 \%$ probability.

$(\mathrm{E} 1=$ floral stem with $30 \mathrm{~cm}, \mathrm{E} 2=$ opening of the first flowers, $\mathrm{E} 3=$ formation of the first silique, $\mathrm{E} 4=50 \%$ silique formed)

The increase in seed production of the best treatment (T10) compared to the control plants that did not receive foliar application of calcium was about $95 \%$ for the seed weight and $120 \%$ for the number of seeds per plant. In addition, the results of the T10 and T11 treatments were numerically much higher than those reported by Cardoso et al. (2016) for the same cultivar: maximum yield of $20.72 \mathrm{~g}$ and 6.060 seeds per plant, thus more than $100 \%$ difference. 
The cauliflower is induced to flower at low temperatures and the earlier flowering occurs, the less leaves are formed and the less inflorescence and seed production (Verdial et al., 2001). The cultivar Piracicaba Precoce is adapted to tropical summer and can not be planted under condition of temperature below $20^{\circ} \mathrm{C}$ that blooms early. Normally the temperatures in São Manuel-SP, place of the research of Cardoso et al. (2016), are lower in relation to Dracena-SP, place of the present research. In the period, average monthly temperatures were 20.0 to $26.3^{\circ} \mathrm{C}$, with an average of $22.6^{\circ} \mathrm{C}$, while the average in São ManuelSP does not exceed $22.0^{\circ} \mathrm{C}$ in the warmer months. Therefore, the induction of flowering later in the conditions of Dracena-SP favored the vegetative development and, consequently, greater potential of seed production. It is also worth noting that there are still peculiarities regarding soil type, management, among others.

It is also noted high productivity in the treatments $\mathrm{T} 10=834 \mathrm{~kg} \mathrm{ha}^{-1}$ (two calcium applications in the last two stages: in the formation of the first siliques and when the plants were with $50 \%$ of the silique formed) and in the treatment T11=960 kg $\mathrm{ha}^{-1}$ (one application in the last stage, plants with 50\% silique formed) (Table 1). These values are twice as high as those obtained by Cardoso et al. (2016) (414 $\left.\mathrm{kg} \mathrm{ha}^{-1}\right)$ and considered excellent according to Maluf and Corte (1990). It probably occurred due to its low mobility in the plant and at the end of the cycle there was a greater demand for the formation of the last seeds and that perhaps calcium was lacking and when applied via foliar supply.

In soybean, Bevilaqua et al. (2002) also obtained higher seed production per plant when applying calcium chloride $(0.5 \% \mathrm{Ca})$ via foliar in the flowering and post-flowering phases. In beans, Farinelli et al. (2006) verified increase in seed yield with application in only one cultivar. Also Rosolem et al. (1990), Javorski et al. (2015) and Silva et al. (2017) applied foliar Ca in the post-flowering phase and obtained an increase in the production of bean, sunflower and Physalis seeds, respectively. Therefore, it can be affirmed that most of the researches show the importance of the application of $\mathrm{Ca}$ in the stage of maturation of the seeds, being a practice that can be recommended. However, Seidel and Basso (2012) and Vanderley et al. (2019) did not observe differences with the foliar application of calcium in soybeans and peanuts, respectively, probably due to the adequate calcium level in the soil and good water availability during the development of the crop. Physiological Ca deficiency is usually related to the inability of the plant to translocate adequate $\mathrm{Ca}$ to the affected plant part, rather than to insufficient $\mathrm{Ca}$ levels in the growing medium (Olle \& Williams, 2017; Hagassou et al., 2019).

The $\mathrm{Ca}$ application did not affected all seed quality characteristics, with mean values of $78 \%$ for first germination count, $89 \%$ for germination, $23.3 \mathrm{mg}$ dry seedling weight, $6.3 \mathrm{~cm}$ length of primary seedling root, $2.6 \mathrm{~cm}$ in length of seedling s shoot, $8.8 \mathrm{~cm}$ in total length of seedlings, $3.9 \mathrm{~g}$ in the weight of one thousand seeds and $129 \mu \mathrm{S} \mathrm{cm}^{-1} \mathrm{~g}^{-1}$ for electric conductivity.

A possible reason for lack of difference in seed quality is the cleaning of seeds, excluding damaged seeds, using only the seeds benefited (Cardoso et al., 2016). It is emphasized that it is a routine procedure done by seed companies (Cardoso, 2011). Besides this, it is common in researches about fertilization in the production of Brassica seeds the absence of difference in seed quality (Magro et al., 2010; Cardoso et al., 2016). Delouche (1980) comments that plants have developed an extraordinary adaptability in adjusting seed production to the available resources. A plant's typical response to some stress, such as nutrient deficiency, is a reduction in the number of seeds produced and only after that a reduction in quality happens. From the evolutionary standpoint, the seed production adjustment to the available resources has a high survival value. The few high quality seeds would have better chances to germinate and develop under adverse conditions.

Also Bevilaqua et al. (2002) did not detect influence on the quality of soybean seeds with foliar application of Ca. In contrast, Rosolem et al. (1990), Farinelli et al. (2006) and Silva et al. (2006) reported superior quality on bean seeds with Ca application.

Therefore, it can be stated that most of the research already carried out shows the importance of the application of Ca in the seed maturation phase, contributing to the increase of seed yield without impairing the quality, being a practice that can 
be recommended. But, it demands more researches, because the results can vary according to genotype, doses, phenological stages and environmental conditions.

\section{Conclusion}

It was concluded that carrying out two calcium applications, one at the beginning of the silique formation and another when the plants were with $50 \%$ of the silique formed, or applying only once when the plants were $50 \%$ silique formed, provided a higher seed production per plant.

Calcium applications at different phenological stages did not influence the physiological quality of cauliflower seeds. Application of these treatments in other cultivars is promising for further studies.

\section{References}

Arantes, R. P., Cury, T. N., Leão, F. D. P. \& Junior, V. A. M. (2009). Foliar application calcium and boron-based calcium chloride and boric acid mixed on income tank for the evaluation of soybean seed. Nucleus, 6, 117-122. https://doi.org/10.3738/1982.2278.206

Bevilaqua, G. A. P., Silva Filho, P. \& Possenti, J. C. (2002). Aplicação foliar de cálcio e boro e componentes de rendimento e qualidade de sementes de soja. Ciência Rural, 32(1), 32-34. https://doi.org/10.1590/S0103-84782002000100006.

Brasil. Ministério da Agricultura, Pecuária e Abastecimento. (2009): Regras para análise de sementesMapa/ACS.

Cardoso, A. I. I. Nutrição e adubação em campos de produção de sementes de hortaliças. In: Hortaliças: Tecnologia de Produção de Sementes. Nascimento WM, Brasília: Embrapa Hortaliças, 109-134.

Cardoso, A. I. I., Claudio, M. T. R., Magro, F. O. \& Freitas, P. G. N. (2016). Phosphate fertilization on production and quality of cauliflower seeds. Ciência Rural, 46, 1337-1343. https://doi.org/10.1590/0103-8478cr20150664

Contreras, S., Farias, A. \& Nascimento, W. M. (2014). Produção de sementes de Brassica oleracea. In: Produção de Sementes de Hortaliças. Nascimento, W. M., Brasília: Embrapa Hortaliças, 45-73.

Dayod, M., Tyerman, S. D., Leigh, R. A. \& Gilliham, M. (2010). Calcium storage in plants and the implications for calcium biofortification. Protoplasma, 247, 215-231. https://doi.org/10.1007/s00709-010-0182-0

Delouche, J. C. (1980). Environmental effects on seed development and seed quality. Hortscience, 15, 13-18.

Farinelli, R., Penariol, F. G., Souza, F. S., Piedade, A. R. \& Lemos, L. B. (2006). Agronomic characteristics and seed physiological quality of common bean cultivars fertilized by foliar application of calcium and boron. Científica, 34, 59-65.

Hagassou, D., Francia, E., Ronga, D. \& Buti, M. (2019). Blossom end-rot in tomato (Solanum lycopersicum L.): A multi-disciplinary overview of inducing factors and control strategies. Scientia Horticulturae, 249, 49-58. https://doi.org/10.1016/j.scienta.2019.01.042

Hosein-Beigi, M., Zarei, A., Rostaminia, M. \& Erfani-Moghadam, J. (2019). Positive effects of foliar application of Ca, B and GA3 on the qualitative and quantitative traits of pomegranate (Punica granatum L.) cv. 'Malase-Torshe-Saveh'. Scientia Horticulturae, $254,40-47$. https://doi.org/10.1016/j.scienta.2019.04.081

Javorski, M., Rinaldi, L. K., Miranda, J., Simonetti, M. P. A. \& Moreira, C. G. (2015). Seed yield of corn as a function of foliar fertilization with calcium and boron on growth stage (V6). Revista Cultivando o Saber, 8, 132-142.

Kano, C., Cardoso, A. I. I. \& Villas-Boas, R. L. (2010). Macronutrient content in lettuce seeds affected by potassium side dressing. Horticultura Brasileira, 28, 287-291. https://doi.org/10.1590/S0102-05362010000300008.

Kano, C., Cardoso, A. I. I. \& Villas Bôas, R. L. (2011). Nutrients uptake by lettuce plants for seed production. Horticultura Brasileira, 29 , 70-77. https://doi.org/10.1590/S0102-05362011000100012

Magro, F. O., Arruda, N., Casa, J., Salata, A. C., Cardoso, A. I. I. \& Fernandes, D. M. (2010). Organic compost in broccoli seed yield and quality. Ciência e Agrotecnologia, 34, 596-602. https://doi.org/10.1590/S1413-70542010000300010.

Maluf, W. R. \& Corte, R. D. (1990). Produção de sementes de couve flor. In: Produção de Sementes de Hortaliças. Castellane, P.D. et al., Jaboticabal: Funep, 77-93.

Olle, M. \& Bender, I. (2009). Causes and control of calcium deficiency disorders in vegetables: a review. The Journal of Horticultural Science and Biotechnology, 84, 577-584. https://doi.org/10.1080/14620316.2009.11512568

Olle, M. \& Williams, I. H. (2017). Physiological disorders in tomato and some methods to avoid them. The Journal of Horticultural Science and Biotechnology, 92(3), 223-230. https://doi.org/10.1080/14620316.2016.1255569

Paiva, A. S., Lopes, M. M., Tesser, S. M., Panobianco, M. \& Vieira, R. D. (2005). Avaliação do potencial fisiológico de sementes de couve-flor. Científica, 33, 103-105. http://dx.doi.org/10.15361/1984-5529.2005v33n1p103-105. 
Research, Society and Development, v. 10, n. 2, e44710212763, 2021

(CC BY 4.0) | ISSN 2525-3409 | DOI: http://dx.doi.org/10.33448/rsd-v10i2.12763

Pereira, A. S., Shitsuka, D. M., Parreira, F. J., \& Shitsuka, R. (2018). Metodologia da Pesquisa Científica. UFSM. 119p

Raij, B. Van, Cantarella, H., Quaggio, JÁ \& Furlani, A. M. C. Recomendações de adubação e calagem para o Estado de São Paulo. 2.ed. Campinas: Instituto Agronómico \& Fundação IAC, 1997. 285p.

Rosolem, C. A., Boaretto, A. F. \& Nakagawa, J. (1990). Adubação foliar do feijoeiro. VIII. Fontes e doses de cálcio. Científica, 18, 81-86.

Seidel, E. P. \& Basso, W. L. (2012). Foliar fertilization with calcium and boron in the cultivation of soybean (Glycine max). Scientia Agraria Paranaenis, 11, 75-81.

Silva, T. R. B., Soratto, R. P., Bíscaro, T. \& Lemos, L. B. (2006). Boron and calcium foliar application on common bean. Científica, 34, 46-52.

Silva, D. F., Pio, R., Nogueira, P. V., Silva, P. A. O. \& Figueiredo, A. L. (2017). Pollen viability and quantification of pollen grains in species of Physalis. Revista Ciência Agronômica, 48, 365-373. https://doi.org/10.5935/1806-6690.20170042.

Vanderley, R. L. R., Silva, T. R. B., Nardeli, A. J., Ducheski, R. L. P., Silva, G. D. \& Lopes, A. C. (2019). Leaf fertilization with calcium and boron on peanut growth in sandy soil. Journal of Agronomic Sciences, 8, 25-31.

Verdial, M. F., Cardoso, A. I. I., Lima, M. S. \& Chaves, F. C. M. (2001). Coincidence of flowering time and the productivity and quality of cauliflower hybrid seeds. Scientia Agricola, 58, 533-539. https://doi.org/10.1590/S0103-90162001000300015. 